2012

\title{
Preparing Preschoolers for Elementary School: A Case Study on KinderCare
}

Amy McCormack

Cedarville University

Follow this and additional works at: http://digitalcommons.cedarville.edu/education_theses

\section{Recommended Citation}

McCormack, Amy, "Preparing Preschoolers for Elementary School: A Case Study on KinderCare" (2012). Master of Education Research Theses. 40.

http://digitalcommons.cedarville.edu/education_theses/40 
Running Head: PREPARING PRESCHOOLERS

PREPARING PRESCHOOLERS FOR ELEMENTARY SCHOOL:

A CASE STUDY ON KINDERCARE

A thesis submitted in partial fulfillment

of the requirements for the degree of

Masters of Education

By

AMY ALLYSON MCCORMACK

B.A. Early Childhood Education, Cedarville University, 2007

2012

Cedarville University 
PREPARING PRESCHOOLERS

\author{
CEDARVILLE UNIVERSITY \\ COLLEGE OF PROFESSIONAL PROGRAMS
}

March 28, 2012

\begin{abstract}
I HEREBY RECOMMEN̦D THAT THE THESIS PREPARED UNDER MY SUPERVISION BY Amy Allyson McCormack ENTITLED Preparing Preschoolers for Elementary School: A Case Study on KinderCare BE ACCEPTED IN PARTIAL FULFILLMENT OF THE REQUIREMENTS FOR THE DEGREE OF Master of Education.
\end{abstract}

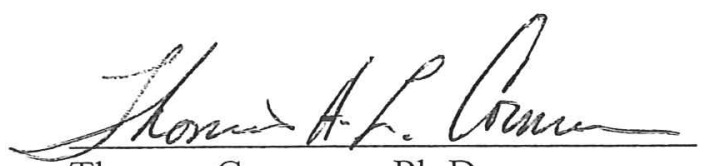

Thomas Cornman, Ph.D.

Academic Vice President

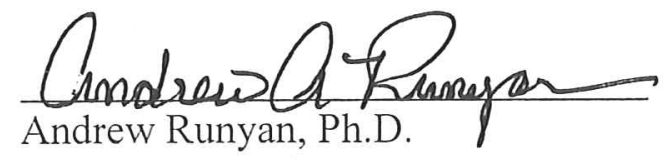

Graduate School Dean

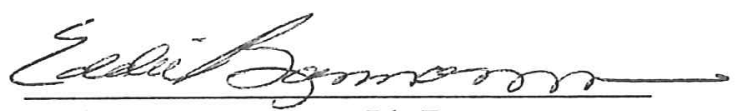

Eddie K. Baumann, Ph.D.

Thesis Advisor
Mark D. MeClain

Mark D. McClain, Ph.D.

Associate Academic Vice President

College of Professions

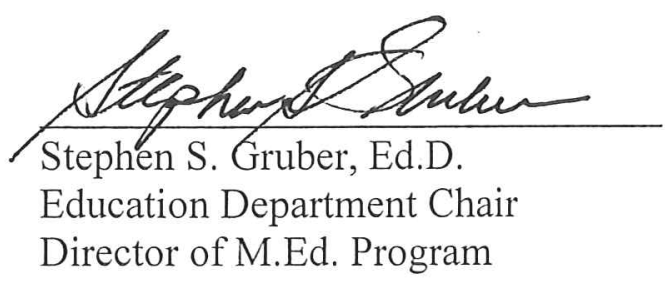




\title{
PREPARING PRESCHOOLERS
}

\begin{abstract}
McCormack, Amy A. M.Ed. Education Department, Cedarville University, 2012. Preparing Preschoolers for School: A Case Study on KinderCare.
\end{abstract}

Preschools ground their philosophies and mission statements in the developmental theories of Frobel, Montessori, Piaget and Vygotsky. These theories address the development of the whole child in an engaging, child-centered environment that stimulates each child's natural sense of curiosity and inquiry through real world experiences. Despite the agreement on developmentally appropriate practices, in recent years a shift towards teacher-directed lecture has occurred. Possible reasons include a ripple effect from No Child Left Behind, a pushed down curriculum, and improper or inadequate teacher training. This case study takes a closer look at KinderCare child care centers through observations and examining their documentation. The National Association for the Education of Young Children accredits certain KinderCare facilities as developmentally appropriate. This study seeks to find if KinderCare follows developmentally appropriate practices and if not to identify the causes or reasons for doing so. 
TABLE OF CONTENTS

I. INTRODUCTION OF THE STUDY
A. Introduction to the Investigation
B. Definition of Terms
C. Statement of the Problem
D. Scope of the Study and Delimitations
E. Significance of the Study
F. Methods of Procedure

II. PLENARY LITERATURE REVIEW
A. Background
B. Preschool Philosophies
C. Developmentally Appropriate Practices
D. Deterioration of DAP
E. Implications for preschool

III. METHODOLOGY
A. Introduction to the Method
B. Rationale for the Method
C. Population of the Study
D. Procedure

IV. RESULTS AND ANALYSIS
A. Introduction
B. Description of the Data 


\section{PREPARING PRESCHOOLERS}

1. Documentation

2. Classroom Practices

3. Environment

C. Data Analysis

1. Documentation

2. Classroom Practices

3. Environment

D. Conclusion

V. DISCUSSION AND IMPLICATIONS
A. Introduction
B. Interpretations of the Results
C. Potential Applications of the Findings
D. Biblical Response and Implications
E. Strengths of the Study
F. Limitations of the Study
G. Suggestions for Future Research 


\section{PREPARING PRESCHOOLERS}

\section{Acknowledgement:}

This paper represents the culmination of three years of classes and work. While only my name appears on this work, I could not have accomplished this alone. I would like to recognize and thank all those involved in seeing this endeavor to fruition.

First and foremost, none of this would be possible without God. He has sustained me through weariness and sickness. He has fought my battles and brought me through the trials I faced physically, emotionally, and spiritually. He provided the strength and encouragement I needed each day. He repeatedly showed me His faithfulness and grace. When I thought I faced the impossible, God miraculously moved the obstacles out of my way and restored my soul to accomplish the task at hand. This paper (and degree) is a result of His divine intervention and unconditional love.

I would also like to thank my mother and father for their continued prayer support and words of encouragement. When I thought I was at the end of my rope, they were there to catch me and push me onward. Thank you, mom, for answering all my late "night" phone calls compassionately to listen and speaking wisdom to my heart. Thank you for never giving up on me, even though I gave up on myself many times. Thank you for not letting me throw in the towel and quit before I finished.

A huge thanks goes to Dr. Baumann for advising me and working with me, faults and all. Thank you for stretching my mind and all you have taught me about teaching and education. You provided a great many resources that made me question and probe the status quo. Thank you for not giving up on me or letting me settle as I wrote this paper; you pushed me to finish strong, as it should be done. 


\section{Chapter 1: Introduction of the Study}

\section{Introduction to the Investigation}

Every fall in the United States, parents head to their local office supply store, department store or super center to buy school supplies for their children. Meanwhile, educators head back to their schools to set up their rooms and check over lesson plans. Teachers evaluate many elements as they work in their classrooms. They consider past experiences and strategies and consult the current best practices in everything from desk arrangements to seat assignments and homework to classroom decorations. At the core of their planning lies the curriculum. What content will the students need to learn throughout the year in order to prepare them for the next year?

Parents, teachers, and administrators have a vested interest in the curriculum taught in their schools. Special committees may be formed to select just the right curriculum materials based on content, budget and the community. Parents want their children to succeed and be prepared for adult life. Teachers use curriculum to map out their lessons, days, units and school year. Administrators aim to meet parent and teacher expectations balanced with state and national standards and requirements.

With almost 80,000 members, The National Association for the Education of Young Children (NAEYC) comprises the world's largest organization concerned about the quality of education for children birth through age eight ("National Association for the Education of Young Children", 2011). For eighty-five years NAEYC has provided 


\section{PREPARING PRESCHOOLERS}

the latest resources and current research in regards to the education of young children. NAEYC outlines their overarching goals as, "improving professional practices and working conditions in early childhood education; supporting early childhood programs by working to achieve a high-quality system of early childhood education; and building a high-performing, inclusive organization of groups and individuals who are committed to promoting excellence in early childhood education for all young children" ("National Association for the Education of Young Children”, 2011).

Snow (2011) understands the symbiotic relationship that exists between research and practice. As teachers apply the latest research findings in their classroom, they also need to provide feedback to researchers for future studies. Unfortunately, the research findings have not always found their way into the classrooms as hoped. Snow explains NAEYC recently set about remedying this problem by creating a center for applied research to provide a link between the two. By providing scores of research findings in teacher-friendly formats, NAEYC hopes to encourage the use of developmentally appropriate practices in early childhood education classrooms. Meanwhile, teachers have the opportunity to provide feedback from their personal experiences which will guide researchers to find developmentally appropriate responses for teachers. This continuous cycle ensures that young children receive quality education.

Rushton and Larkin (2001) note that teachers have long understood developmentally appropriate practices (DAP), but they have lacked substantial research to back their experiential knowledge. Rushton and Larkin use the current body of research about how the brain works and draw correlations to nine DAP position statements. Knowledge of the brain can inform teaching practices based on how the 


\section{PREPARING PRESCHOOLERS}

brain receives, processes, and stores information. Both DAP and brain-research point to a child-centered learning environment as opposed to didactic teaching. Rushton and Larkin include examples of how each DAP position and brain-research principle would look in the classroom.

Brain research offers more than cognitive implications for the classroom; it also offers insights into an effective classroom environment. Rushton, Juola-Rushton and Larkin (2010) discuss how the sense perceptions of the classroom environment can either interfere or enhance student learning. Subconsciously, students quickly assess the classroom environment as inviting and interesting or cold and dull, triggering the "flight or fight" response before the cognitive portion of the brain can adequately ascertain the environment. Once the emotional reaction has occurred, cognitive reality cannot fully compensate. Therefore, the classroom environment needs to welcome and encourage student learning and interests. Rushton, Juloa-Rushton and Larkin correlate DAP, brain research, classroom environment and research conducted by Brian Cambourne on literacy learning to show how to create a sound learning environment.

Blank (2010) recognizes the division between early childhood education and elementary school as play versus academics, child-centered versus teacher-centered, and integrated curriculum versus discipline-based, respectively. She notes historically kindergarten was viewed the same way, however, over the years it has melded into the elementary school model. In recent years, the role and need of preschool has been debated much like kindergarten. Programs such as Head Start expose at-risk preschoolers to a rich learning environment in order to prepare them for the academics of kindergarten. At the same time, the need for childcare and school-readiness has brought 


\section{PREPARING PRESCHOOLERS}

universal preschool requirements into question. Preschool faces the same debates kindergarten faced at its inception; how to integrate with formal education while remaining true to DAP? Blank focuses on how this affects training "high-quality" early childhood professionals and the route kindergarten has taken.

Bryant, Clifford and Peisner (1991) agree that the multiple purposes of kindergarten to academically, socially and emotionally prepare students for school have hindered wide-spread agreement on a method or theory for teaching kindergarten. Looking at NAEYC guidelines and preschool studies in light of current kindergarten practice provides insight into the relationship between DAP and kindergarten classroom practice. The study did find a correlation between principals and teachers and their beliefs in DAP or didactic instruction. Those that had a good understanding of DAP tended to have more developmentally appropriate classrooms, however, only twenty percent of the kindergartens studied qualified as developmentally appropriate based on observations and interviews.

With so much research available on DAP through NAEYC and collaboration from brain research preschools should provide a rich learning environment for children to develop naturally. After researching the progression of kindergarten, however, preschool stands on the brink of succumbing to abandoning DAP in light of didactic instruction and cognitive development at the price of social and emotional development. A closer look at how preschools prepare their students for kindergarten and elementary school will shed more insight in how preschools handle the divide between DAP and didactic instruction. 


\section{PREPARING PRESCHOOLERS}

\section{Definition of Terms}

DAP: "Developmentally appropriate practices result from the process of professionals making decisions about the well-being and education of children based on at least three important kinds of information or knowledge: what is known about child development and learning; what is known about the strengths, interests, and needs of each individual child in the group; and knowledge of the social and cultural contexts in which children live. Furthermore, each of these dimensions of knowledge is dynamic and changing, requiring that early childhood teachers remain learners throughout their careers." (Bredekamp and Copple, 1997, pg. 8-9)

KinderCare: "KinderCare Learning centers is owned and operated by Portland, Oregonbased Knowledge Learning Corporation, the nation's leading private provider of early childhood education and care. KinderCare Learning centers comprises approximately 1,700 community-based centers in 38 states and the District of Columbia serving more than 300,000 children and employing approximately 41,000 people” (KinderCare, 2012).

NAEYC: The National Association for the Education of Young Children, founded in 1926, "is the world's largest organization working on behalf of young children with nearly 80,000 members, a national network of more than 300 state and local Affiliates, and a growing global alliance of like-minded organizations." NAEYC offers conferences, meetings, and professional development resources; awards accreditation; prints periodicals and books; supports public policy and advocacy based on their standards; and continues to invest in association relations. (National Association for the Education of Young Children, 2011) 


\section{PREPARING PRESCHOOLERS}

No Child Left Behind: NCLB is part of the 2001 revision of the Elementary and

Secondary Education Act (ESEA) originally signed into law by President Johnson in 1965. ESEA “is the main federal education law, describing federal requirements for the nation's public schools, most of which receive some form of aid under the statue, Public Law 107-110" (National Education Association, 2012). NCLB also stipulates Adequate Yearly Progress must be made by schools according to the accountability standards set in place by the law.

\section{Statement of the Problem}

Research abounds on the best classroom practices, learning styles, assessments, classroom management and curriculum. Teachers and administrators attend conferences yearly to learn better ways to teach and reach the students in their schools. Teachers communicate with other teachers in their building and district to learn from each other and stay up with the latest improvements. Parents voice their concerns and inquire about the practices and curriculum used in their child's classroom. The education of children receives a significant amount of attention in order to best prepare this generation of learners for life outside and beyond the classroom.

Typically at the preschool level, social interactions comprise most of the day. Teachers encourage children to explore and learn through play; whether independent play, or with a group of friends, or with educational resources. The teacher may or may not structure this time, but in any case, students learn the basics in order to prepare them for the rest of their education. Basics about sharing, disputes, authority, orderliness and other such behaviors and expectations in the school and classroom are learned for the first time. Yet a delicate balance has emerged between cognitive development and 


\section{PREPARING PRESCHOOLERS}

preparation for later academics and the need to help children develop socially, emotionally and physically.

Research abounds on best practice and DAP on almost every topic imaginable in the classroom and school setting. Right alongside the research stands government imperatives for No Child Left Behind (NCLB) and the ability/need for younger children to learn to read and write. This implies children need less play and creativity and more academic instruction in order to be ready for kindergarten, while at the same time learning in a creative child-centered environment in order to develop the whole child. Preschools face the challenge of finding a balance between NCLB and continuing to develop the whole child. In order to reach a balance, what are preschools compromising on and to what detriment to their students? Naturally, parents what to hear that their children will receive the best preparation for kindergarten, including academic progress, while using best practices. Despite the typical mutual exclusivity of the two, preschools everywhere claim both can be and are achieved in their school. So what exactly is taking place behind the classroom doors?

\section{Scope of the Study and Delimitations}

This research will be conducted as a case study looking at a particular KinderCare child care center. Since KinderCare operates nation-wide, they have specific guidelines for uniformity among locations. This includes general practices, which provides transferability between the branch studied and other KinderCare centers. It also will allow a better ease of access to the information due to the standardization of material provided by the KinderCare Corporation. The National Association for the Education of Young Children (NAEYC) has accredited KinderCare facilities, acknowledging the high 


\section{PREPARING PRESCHOOLERS}

level of quality education provided. This validates the soundness of the program and reduces the possibility of community bias or a local culture. KinderCare offers programs for infants through kindergarten based on a single year age-group.

Due to the variability of community childcare facilities, this study will not include an examination of them. Some facilities simply watch children without providing any kind of structure or school preparation. Other facilities offer a varying degree of structure and academics that would complicate this study's main purpose. Since each facility works independently, these facilities lack continuity with other facilities, which make generalization of results difficult. Other corporate facilities were considered; however, KinderCare provided the necessary requirements and agreed to participate.

This study will evaluate how KinderCare attempts to balance DAP and academic preparation for kindergarten. Observations of the facility, along with classroom observations, will provide qualitative data on their curriculum and the practices they use. This research looks to add more information to the gap between research practices and actual classroom practices. The results should provide teachers and administrators more information for their further analysis and investigation.

\section{Significance of the Study}

KinderCare falls under the larger corporate umbrella of Knowledge Learning Corporation. With facilities all across the nation, KinderCare employs a significant number of teachers and administrators, and they reach an even greater number of parents and children. Due to their size, KinderCare also represents a framework, not only for the other companies under Knowledge Learning Corporation, but also for childcare facilities 


\section{PREPARING PRESCHOOLERS}

nation-wide. The results found in this case study can provide a mirror by which other facilities can examine their current DAP and academic practices.

For many children, the first, and therefore, a critical encounter with schooling, occurs during preschool. Values, behaviors and expectations required for elementary school and general education find their beginnings here; even before formal education begins in kindergarten. Teachers and administrators should know and understand why they follow certain policies and practices beyond historical/mandated reasons.

Parents send their children to school to get an education and further their prospects for later in life. They may not be familiar, however, with the research on best practices or the implications of government mandates. Oftentimes parents depend on facilities like KinderCare to provide sound educational structure for their preschoolers rather than hiring a babysitter. For many young parents, or first time parents, “curriculum" represents a novel concept they have not given much thought, let alone DAP or other considerations involved with early childhood education. Parents have a vested interest in all areas of their child's learning and should stay properly informed by the facility they choose.

\section{Methods of Procedure}

The research will start by analyzing the policies and procedures outlined in the KinderCare Family Handbook and their website. Content will be reviewed in terms of child-centered (c-c) or teacher directed (t-d) and in terms of DAP or didactic instruction (di). After the data collection, a visit will be made to the facility to observe the overall environment. This includes surveying the building for signs, posters, pictures, bulletin boards, welcome center, and promotional paraphernalia. The structure, design, 


\section{PREPARING PRESCHOOLERS}

furnishings, and layout of the school and grounds will be noted. No interviews or direct interaction will occur with the students or teachers, instead, just monitoring the classrooms and observing other student domains. Documentation will consist of written field notes as well as personal tape recordings of verbal notes. These notes will also be coded according to c-c and $\mathrm{t}-\mathrm{d}$ as well as DAP and di.

McMullen et al. (2006) conducted a similar study in which the researchers compared teacher's beliefs with their practices. They started with a survey for participating teachers to complete. They followed up with observations in the classroom through time samplings and analyzing the environment. Both findings were coded for DAP or "traditional" practices with allowance for DAP practices seen in traditional classrooms. Instead of conducting a survey, this study will reference the company's standings as outlined in their handbook and website. Classroom observations will replicate that of McMullen's study and include environmental factors. 


\section{Chapter 2: Plenary Literature Review}

\section{Background}

Friedrich Frobel, while always interested and involved in teaching, did not find his true calling until his mid-fifties. At that time, he had taken note of nursery centers for young children and put together all his years of experience and learning to develop his own "children's garden" in which he accepted children from one to seven years of age (Woodard, 1979). Frobel created "gifts" or objects children could manipulate to learn about various mathematic principles that gradually introduced more difficult concepts from colors to planes. He also developed various "occupations" in which children developed fine motor skills through cutting, sewing and crafting. Throughout the day as an extension of the home environment, Frobel employed "mother plays" such as songs, rhymes and finger plays.

According to Woodard, Frobel's original curriculum allowed for individual exploration of mathematical concepts. The teacher provided a spoken commentary for language development and guided learning of all possible lessons each gift and occupation offered. Each gift had the ability to portray "forms of life", "forms of beauty", and "forms of knowledge". In this way, Frobel taught the value of practicality, creativity and academics. Frobel understood each child develops and unfolds at his own rate; much like a flower and much like a flower grows in a nurturing environment, so too the child needs a nurturing environment in which to grow and develop. He caught a 


\section{PREPARING PRESCHOOLERS}

vision for children to explore and experiment with the world around them at a time when structure and lecture dominated the educational field.

Frobel saw play as a time for children to explore nature and realize their unity and connection to the world; a key principle in his own beliefs. Through these experiences, children would develop academically and inwardly as a whole human being. Unfortunately, Frobel's followers lost sight of his vision of student-centered learning and instead started producing a scripted curriculum for teachers to follow, rather than following the cues of each individual student. Manning (2005) notes the events that lead to the eventual demise of Frobel's kindergarten in America between commercialization of the gifts, the loss of student-centered curriculum, adapting it for societal problems, tensions from WWI with Germany, and ultimately science and behaviorism. Frobel's followers adapted his kindergarten in order to socialize the large influx of immigrants and shifted away from the objects which had become commercialized as educational toys for children; leaving kindergarten more teacher-directed. The war against Germany caused Americans to cut all ties with Frobel and his Germany heritage. At the same time, this provided an entrance for psychologists interested in the science of behaviorism which overtook the educational field. Manning suggests that despite the misinterpretations of his followers, perhaps Frobel's basic tenets of play and exploration still provide a good foundation for kindergarten learning.

Like Frobel, Maria Montessori led a varied life before she started what has become the Montessori educational philosophy. Gutek (2003) notes that during her time working in a psychiatric hospital in the pediatric ward, Montessori researched and documented the ways children learned best. From her scientific findings she began to 


\section{PREPARING PRESCHOOLERS}

develop her own way for training young children. Montessori (1967) notes three stages of development: birth to age six, age six to twelve, and age twelve to eighteen. She further separates stages one and three into two phases; stage one phase one: birth to age three, phase two: age three to six, and stage three phase one: age twelve to fifteen, phase two: age fifteen to eighteen. She points out that physical changes, as well as educational changes mark each developmental stage (e.g. losing teeth, puberty, starting school). Montessori concludes that a great deal of emphasis is placed on education after age eighteen when she feels development is complete, while little, if any, attention is given to children from birth to age six where the foundation of all learning beginnings.

Montessori identified two internal features in children birth through age six that indicates an order to their development and the need for specific educational considerations (Lillard, 1972). First, she believed children progress through five sensitive periods; desire for order and consistency, exploration through hands and tongue, walking, fascination with tiny objects (such as bugs), and having community with others. Lillard explains the second feature, the absorbent mind, as the way children understand the information they gain through the sensitive periods. With this in mind, Montessori developed an environment to enrich the sensitive periods and fuel the absorbent mind in her pre-school settings. The specific materials she used fit into four basic categories; daily-living exercises (physical care for self and environment), sensorial, academic, and cultural and artistic materials (Lillard). Montessori believed the environment allowed children to develop while revealing their natural personality.

Other key influences to early childhood education include the work and philosophies of John Dewey, Jean Piaget and Lev Vygotsky. All three men believe 


\section{PREPARING PRESCHOOLERS}

children are active learners and should be engaged in their learning. Dewey thought school should provide children with authentic life experiences which would integrate content and increase in difficulty (Bredo, 2003). Teachers provide a rich environment to stretch and grow students by presenting real life problems for students to solve (Bredo). Dewey used what he termed "occupations", or activities reflecting jobs in society, in order to provide lessons in context and maintain children's active, natural curiosity and interests (Boisvert, 1998).

Like Montessori, Piaget studied the development of children and found four stages of development; Sensorimotor Period (birth to 24 months), Preoperational Period (ages 2-7), Period of Concrete Operations (ages 7-11), and Period of Formal Operations (adolescence). Children begin their preschool experience during Piaget's Preoperational Period in which they begin to develop language and explore the world around them (Singer \& Revenson, 1997). During this period, Piaget notes the importance of play which allows children to develop vocabulary, concentration, flexibility, creativity and imagination, and empathy (Singer \& Revenson). This avenue of learning allows children to construct meaning through adaptation; a dual process of assimilation and accommodation.

Although not as directly influential in preschool development and education, Vygotsky's educational contributions have found their way into preschools. While Vygotsky's theory explores three interrelated factors, the United States tends to focus mainly on his theory of the Zone of Proximal Development and the individual (Tudge \& Scrimsher, 2003). The teacher and student interact bi-directionally in order to move the student beyond his current independent abilities and stretch him through guided practice 


\section{PREPARING PRESCHOOLERS}

until he reaches his limit and depends on the teacher for further help; this his zone of proximal development (Trudge \& Scrimsher). The teacher uses the process of scaffolding to introduce new information little by little in order to help the student reach new levels of learning.

\section{Preschool Philosophies}

Spodek and Robison (1965) explain, as society changes, so too, schools must change to meet the expectations of training students for the culture in which they live. Much of Frobel's kindergarten portrayed the symbolic world and pointed to understanding the unity between man and God, and man and nature. Despite Frobel's kindergarten philosophy of a child-centered environment resonated with Americans, his abstract thinking of unity with God and nature and his European mindset confused teachers and children alike. Patty Smith Hill, an American educator, believed kindergarten should encourage a social environment and take into account the student's personal experiences. Hill focused on the concrete basics of life through child-centered activities and play things. Her new kindergarten curriculum borrowed from Frobel and Montessori while adding in the American standards, blocks and dolls, to teach the basics of life, rather than to understand the symbolic nature of life. Other reformers included Lucy Sprague Mitchell who believed children learn best in familiar social contexts, so she developed a curriculum for nursery school up to junior high focused on educating through social studies. Caroline Pratt, like Frobel, saw play as the free, unstructured expression of children learning prior to written language skills; therefore, she left no written curriculum to follow in the hopes her followers would stay attuned to each individual child's needs. 


\section{PREPARING PRESCHOOLERS}

The mental health of young children took the stage in the 1940's and 1950's and psychiatrists asserted that most adults' problems stem from issues encountered during their childhood years (Spodek and Robison, 1965). Creativity and less structure became the key to optimal development in order that children could express their feelings and have greater freedom to develop naturally. According to Spodek and Robison, this led to the deterioration of the kindergarten because teachers became uncertain of their role in the classroom and afraid to discipline or instruct. In the 1960's Spodek and Robison suggested in compensation to this deterioration, kindergarten programs needed to include language, math, social studies and science readiness skills. Additionally, the whole child still needs to develop, so individuality, variety and flexibility must be part of kindergarten in order to match the unique variety of students in the class.

Creativity stands at the foundation of the Reggio Emilia Approach, founded in the small town of Reggio Emilia, Italy. Thornton and Brunton (2010) explain how Loris Malaguzzi left her legacy of 100 languages of children and the atelier as the basic tenets to Reggio Emilia today. She understood children have many different ways in which they express themselves and learn from the world, hence the 100 languages of children. This can be seen in their atelier or studio/workshop area in which children freely create short-term or long-term projects their atelieriste (teacher) has designed based on student interest. Teachers do not use documentation in order to plot student development, but rather, to see where students' interest lies and what means they can use to encourage exploration and learning in those areas. Environment also plays a large role in the Reggio Emilia Approach. Not only should the classrooms reflect student artwork and 


\section{PREPARING PRESCHOOLERS}

interests, but even the kitchen and bathroom should reflect a home atmosphere above a practical function.

Strong-Wilson and Ellis (2007) expounds on the Reggio Emilia classroom. Here, the teacher is part of a triad of educators; the child and the environment complete the trio. Strong-Wilson and Ellis focus on this last element (the environment) for teachers to consider. By providing unexpected objects in the classroom for children to explore, the teachers can listen and document how the children react. These notes then provide the basis for the next step in the learning process based on the children's interests. StrongWilson and Ellis also point out that children enjoy creating their own special space usually in the least likely place out of the least likely elements. Oftentimes teachers create spaces for children based on preconceived ideas. Strong-Wilson and Ellis encourage teachers to think carefully about classroom environment and children spaces.

While Reggio Emilia focuses on creative thinking and fostering expression through art, Linder, Powers-Costello, and Stegelin (2011) note it also fosters mathematic skills through project work, recycled materials, art and play. Children explore mathematical concepts such as number sense and one-to-one correspondence through real-life experiences and daily routine activities. As children work through projects, teachers weave the need for mathematics into finishing the projects. Linder et al. believe this early introduction to mathematics will encourage students to continue to show an interest in mathematics throughout their education. The Reggio Emilia Approach allows students to explore and actively engage in mathematical concepts, rules and procedures.

Not only does this natural inquiry encourage mathematic skills, it also encourages science integration. Inan, Trundle, and Kantor (2010) point out that science should not 


\section{PREPARING PRESCHOOLERS}

be taught in isolation as its own curriculum. They recognize the value of project-based inquiry such as the Reggio Emilia Approach offers. In order to emphasize the integration of science in the classroom, the authors conducted an ethnographic study and charted the science topics covered and how they overlapped into other units of study. The study found that these units of study directly related to state science standards and covered a large percentage of the standards. Inan, Trundle, and Kantor conclude that the Reggio Emilia Approach and inquiry method provides a solid base to teach science.

Lim (2004) looks at three different early childhood schools and their theory on art and painting. The Bank Street Approach takes its philosophy from Piaget's cognitive stage theory in which teachers present art and learning in developmentally appropriate steps. The Reggio Emilia Approach holds more to a Vygotskian philosophy by stretching children in their zone of proximal development while scaffolding them to a higher level of education. Lastly, the Waldorf approach views education through a spiritual, inner strength based on the founder, Rudolf Steiner's beliefs. All three agree that art plays an important role in early childhood development and education. Art is not a time for children to simply play with different mediums, but rather, a time for a true expression of the basic tenets each approach above espouses.

Schwartz (2008) takes a closer look at the Waldorf Approach and how they prepare preschoolers for later education. Creative real life experience as a child provides the necessary backdrop for application of knowledge in higher grade levels. Children store memories of actively doing in their formative years, which they recall later in life in order to build deeper connections about a concept. One example Schwartz uses regards the use of a common piece of playground equipment - the teeter-totter. Young children 


\section{PREPARING PRESCHOOLERS}

enjoy learning how to balance the plank such that each side easily goes up and down. They soon learn how to add more friends and still swing up and down, and the consequences for not having a balanced plank. Later in life, this experience helps them understand the principles of a lever. According to the Waldorf Approach, educational toys present only one right answer with little to no room for creativity; whereas these life experiences open the door to several implications and applications for higher education.

\section{Developmentally Appropriate Practices}

Copple and Bredekamp (2008) outline common developmentally appropriate practices (DAP) and developmentally inappropriate practices (DIP). DAP include, "curriculum and experiences that actively engage children; rich, teachersupported play, integrated curriculum; scope for children's initiative and choice; intentional decisions in the organization and timing of learning experiences; and adapting curriculum and teaching strategies to help individual children make optimal progress" (pg. 54).

DIP includes,

"highly linear instruction, especially when it follows an inflexible timeline; heavy reliance on whole group instruction; fragmented lessons without connections that are meaningful to children; rigid adherence to a packaged, 'one size fits all' curriculum; teachers following a predetermined script without regard to children's responses; highly prescriptive requirements, along with rigid timelines for achieving them; and narrow focus (for example, only on literacy and math instruction" (pg. 54). 


\section{PREPARING PRESCHOOLERS}

While some items fall easily into categories of appropriate or inappropriate, other items find unquestioned acceptance or rejection. Copple and Bredekamp encourage teachers to scrutinize why they use or do not use certain practices. Structure or the lack thereof is not enough to accept or reject certain practices; some may have a time and place in developmentally appropriate practices.

Developmentally appropriate practices provide hands-on experiences that allow for the exploration of science, technology, engineering and mathematics (STEM) even in preschool. Moomaw and Davis (2010) take a look at a preschool inclusion classroom in which a STEM curriculum is being developed. Highlights include students learning the sounds of common birds and the hand position for each note (the Kodály method) as well as exploring pendulums. Even non-verbal students could identify bird sounds and give the correct hand positions. Students have the opportunity to explore and manipulate materials, laying the foundation for higher level thinking and content.

Vartuli and Rohs (2008) explain the importance of intrinsic motivation in students to become life-long learners. Teachers can help foster a desire to learn by engaging students in topics of interest and providing hands-on experiences. Students will exert more effort for a longer period of time when an activity interests them. The authors provide several ways in which teachers can "negotiate" lessons such that students can actively take part in learning while at their own pace and interests.

In order to individualize lessons to reach each student, small group activities can help provide homogenous groupings. These small groups facilitate a high quality preschool education. Wasik (2008) provides seven guidelines to help teachers create the ideal small group. Teachers need to remember group size, purpose and goal when 


\section{PREPARING PRESCHOOLERS}

creating group activities, but they also need to take an active and deliberate role during the group learning. By properly implementing small groups, teachers can increase language development, children's engagement, and positive interactions. Less time is spent on managing children so more time can be spent on tailored instruction and scaffolding information while providing more time for assessing children individually.

Universal Design provides another way to reach all students, especially those with special needs and in inclusion classrooms. Darragh (2007) discusses the five components of Universal Design for Early Childhood Education along with a diagram of how the pieces overlap and affect each other. Students learn best from multiple means of representation, engagement and expression. This does not include traditional teaching methods of lecturing or worksheets. They also need multiple means of access which keeps in mind equity and accountability.

When it comes to literacy, reading readiness has taken a backseat to emergent literacy skills. Parette, Hourcade, Dinelli, and Boeckmann (2009) clarify that reading does not happen in a specific sequence, but rather through the development of five literacy areas: phonemic awareness, word recognition, concepts of print, alphabetic principle, and comprehension. The best practices integrate reading and writing in order to develop each of these five areas. Parette et al. purport that a new software program, Clicker 5, perhaps helps in this way, although further conclusive research is needed. The program not only helps combine reading and writing, they also follow developmentally appropriate practices by engaging students and meeting their interest and ability levels.

Given the opportunity, children naturally relate life through language, either verbal or written. Quintero (2010) expounds on this point through her various 


\section{PREPARING PRESCHOOLERS}

interactions in early childhood settings. Children readily express their lives through stories and social play. Teachers can use these opportunities to expand vocabularies, understand background knowledge and experiences. Quintero provides several ways to encourage children's natural communication through reading and writing activities. Instead of enforcing a certain set of prefabricated knowledge and skills, teachers should build lessons around the knowledge and skills students come to school possessing.

Developmentally appropriate practices encompass a wide variety of educational practices; even at graduation time. Taharally and La Fontaine (2007) reflect on traditional school graduation practices in preschool. Rather than adopting these ceremonies that add more stress than enjoyment to parents, teachers and students alike, they suggest remembering DAP and enjoying preschool for what it embodies. In other words, the rigors of the traditional college, then high school, and even middle school and elementary school do not belong in the preschool environment. Taharally and La Fontaine suggest creating a memory book throughout the year to highlight accomplishments, happy times as well as sad times. Parents can come to the classroom to listen to a few favorite finger plays or songs the students have learned over the year and then partake in simple light refreshments. This celebrates each individual child, while not overwhelming them with crowds of strangers.

In recent years, with the No Child Left Behind mandates and state standards, DAP have begun to take a backseat to traditional teaching methods of lecture and worksheet. Brumbaugh (2008) offers an acronym to remember to implement DAP despite the NCLB mandates - RESPECT: relationships, experiences, space and security, play, expectations, caring, and time. Teachers should encourage communication with parents and invite 


\section{PREPARING PRESCHOOLERS}

parents to volunteer in the classroom. Relationships should also be nurtured among students to build teamwork and learn from each other. The classroom environment should allow for hands-on experiences as well as plenty of space to move. Students should feel safe and secure in their classroom which will encourage them to explore and make mistakes while learning. Students should have plenty of time and materials in order to develop socially, emotionally, physically and cognitively through play. Teachers should have high expectations for students in order for them to rise to the occasion and develop their gifts and abilities. While some lessons need time structuring, the day should operate on a flexible time schedule to allow students to grow and develop at their own rate. This type of environment respects DAP while respecting the child.

\section{Deterioration of DAP}

Developmentally appropriate practices focus on children eight and under with a clear understanding of how children develop. Graue (2008) notes that DAP have not found their way beyond age eight nor have they received much welcome from elementary schools. One reason for this, she asserts, revolves around the fact that DAP's authority comes from an understanding and belief in development. Unfortunately, when it comes to standards in elementary school, Graue explains third or fourth grade represents the starting point for content mastered. From there, the lower grades receive standards in order that students will reach the end goal; even if that means inappropriate expectations in kindergarten. This practice focuses on cognitive development at the expense of other developmental areas (social, emotional and physical).

The need for play carries over into the elementary school where recess provides the single outlet. Powell (2007) follows the dynamics surrounding one school's unique 


\section{PREPARING PRESCHOOLERS}

activities during recess. Instead of playing on the top-of-the-line soccer field, students at this school chose to play in the surrounding woods building forts. Here, they have devised their own set of rules for building and maintaining forts and fort membership. Originally, students simply practiced these rules; however, in the end teachers encouraged some of the more important rules be written down to help maintain order. Throughout each year and the years students attend the school; boys and girls actively pursue fort building. Powell attributes this to "children's greater tolerance for chaos and flexibility and their need to exercise their own decision-making powers" (2007, pg. 87). He concludes by stating, "recess provided some of their most cherished memories of life at the school. It may also have provided some of their most valuable lessons" (2007, pg. 102).

In the early childhood settings, dramatic play should hold a key position in classroom scheduling and routine. Rogers and Evans (2007) voice a concern that dramatic play is being inhibited in the preschool classroom. In the classrooms they researched, noise level, activity space and time allotted for dramatic play created problems for both the teachers and students. Dramatic play time now shares its allotment with literacy and numeracy learning. Less time and room to creatively play increases noise levels and tight places to explore. Rogers and Evans found these problems interfered with students and teachers realizing the full potential of dramatic play in the students' development. Rogers and Evans suggest teachers taking a more child-centered approach and include students input in creating the classroom practices and layout; bringing back the purpose of play. 


\section{PREPARING PRESCHOOLERS}

Brownlee and Berthelsen (2006) investigated the relationship between personal epistemology and classroom practices in early childhood classrooms. They found that teachers with a higher level of education had a larger repertoire of strategies and classroom practices. This allowed them the flexibility to meet each student's needs, versus teachers who had a narrow understanding and practice. Research showed a strong correlation between personal factors such as epistemology and teaching practices, and outcomes. Based on their research, Brownlee and Berthelsen encourage teachers and preservice teachers to analyze their personal epistemology which directly and indirectly impacts their teacher practices and outcomes.

Tension has arisen between teacher authority and child-centered classrooms. Langford (2010) notes the research that links teacher authority with passive students waiting for teachers to fill up their minds with knowledge. This is not, however, the only way to have authority in the classroom she argues. Langford explains teacher authority can be seen through knowledge, judgments and will. Knowledge in this case is seen as skills and tools the teacher uses to guide and facilitate learning; not as a lecturer, but an expert in selecting classroom practices. Selecting the appropriate methods or materials for lesson plans and daily school routines comes from the teacher's authority in judgments. Since teachers have uncontested control over their classrooms according to their will (desires), Langford suggests an ethical approach in which decisions are made in regards to the greater good of the classroom. Teachers can use their will to benefit the students through power-sharing with the students' voice. Teachers can have authority in these three elements without operating their classroom like a dictatorship. 


\section{PREPARING PRESCHOOLERS}

Tzuo (2007) came to a similar conclusion based on research from Piaget's and Vygotsky's theories and Dewey's and Montessori's educational philosophies. Tzuo questions the basic premise of child-centered classrooms in early childhood education and how that impacts the teacher role or authority. He concludes that a child-centered classroom does not mean the child runs the classroom or that the teacher cannot have authority in a child-centered classroom. Rather, the child is free to actively interact within the classroom while the teacher actively seeks to engage the students and facilitate their learning. Tzuo (2007) hopes, "this article encourages each early childhood teachers to create their own child-centered classroom through vividly incorporating multiple theories in various beautiful, creative, and harmonious ways" (pg. 39).

\section{Implications for Preschool}

In 2002 No Child Left Behind began to enforce annual yearly progress goals on all schools in order to maintain their federal funding. Powell, Higgins, Aram, and Freed (2009) examine the results of NCLB on scheduling in the elementary classroom/school. They found that in instructional time reading and mathematics increased while science and social studies decreased. In non-instructional time, art, music and physical education remained about the same, while recess and nap time (in kindergarten) decreased. Powell et al. conclude that, "the pressures of NCLB has caused many teachers to adopt teaching methods that lack innovation and creativity often leaving teachers to feel that they are unable to use their professional judgment about what's best for their students" (2009, pg. 27).

As part of the 2008 (Instructional time) report in the series From the Capital to the Classroom: Year of the No Child Left Behind Act, five tables indicate the effect on 


\section{PREPARING PRESCHOOLERS}

elementary classrooms and instruction time as well. As noted above, instructional time for reading and mathematics increased while science and social studies decreased. Time allowed for lunch, recess, art, music and physical education also saw a decrease of an average of 75 minutes according to the findings.

Trunnicliffe, Chatterton and Arcari (2006) took a closer look at the effect of less time for physical education in the elementary schools. With a rise of childhood health concerns related to lack of exercise resulting in obesity and diabetes, the authors fear childhood will disappear. High-stakes testing only focuses on the cognitive part of the child, avoiding the rest of the child, more specifically the physical health aspect. In addition, children spend more of their time sitting, rather than engaging in physical activities. Trunnicliffe et al. would like to see NCLB include a health initiative so children make it to a healthy adulthood; or adulthood in general.

While NCLB has affected elementary school as a whole, kindergarten provides a link to preschool. Originally, kindergarten represented the "stepchild" of education, but time has seen how kindergarten has become a part of formal education. Fernie (1988) looks at two siblings about to start school, one going to preschool, the other to kindergarten. Once sharing a similar philosophy and mindset as preschool, kindergarten has replaced play with more academic content and follows the philosophy of elementary schools. Fernie explains the two philosophies as "socialization-to-school" (preschool preparing students for community at school) and "socialization-through-school" (elementary schools preparing students for the workplace) (1988,pg. 4). As kindergarten requirements continue to increase, so too, the expectations for preschool will face the same predicament as to the purpose of schooling. Fernie cautions that simply attending a 


\section{PREPARING PRESCHOOLERS}

half-day preschool program starting at age three, two thousand hours of school will be clocked before formal education in kindergarten begins.

Ray and Smith (2010) agree that Frobel's kindergarten has been replaced. Instead of free exploration, imagination and curiosity, students face academic standards and assessments. No longer able to develop according to their own nature, kindergarten students must now perform in line with national accountability standards. Ray and Smith warn that this trend in education ignores the DAP which may cause complications for students and schools in the future.

Alarmed by the decrease of playtime in kindergarten, Nicolopoulou (2010) offers some practical ways to use play for academic purposes. She does not imply young children should not learn reading and writing or mathematics; merely that young children learn differently than adults or even older children. Unstructured play is not the antithesis of didactic teaching -- play can provide the catalyst for learning in developmentally appropriate ways for preschoolers. Nicolopoulou calls for a middle ground between direct instruction, which may prove harmful for students in the long run, and free play time. She hopes that teachers can develop ways to actively engage students in academics while developing the whole child.

Freeman and Hatch (1989) studied kindergarten report cards in order to better see what schools expect of students. They coded the skills based on three philosophies: maturationism, behaviorism, and interactionism. Maturationism believes children develop biologically, behaviorism believes children develop based on environmental/nurture influences, and interactionism believes children develop naturally as they interact with the environment/nurture. Nearly half of the report cards held a 


\section{PREPARING PRESCHOOLERS}

strictly behaviorist philosophy in which the teacher dispenses skills/information for the students to master. The rest had strong behaviorist leanings with either a few maturationism and/or interactionism goals. Most notably, report cards reflected work habits and reading and math readiness. Freeman and Hatch show concern that from a behavioristic perspective students can fail kindergarten whereas the maturationism and interactionism views hold the premise that children develop at different rates over time.

As kindergarten began to meld with elementary school, the preschool phenomenon began to take root in the early 1980's. Suransky (1983) conducted a two year ethnographic study of five different types of preschools. Even at that time, she found preschools requiring students to listen quietly to teachers during designated learning times. Students who investigated supplies in ways other than intended found themselves disciplined and ostracized from the group. Suransky remarks, "play, which is fundamental to the social, cognitive, and emotional development of every child, becomes deviant within such a structure" (1983, pg. 29). Rather than meeting the needs of the children, her concern is that these facilities do no more than contain children while their teachers learn better ways of managing them.

Fast forward twenty years and Stipek (2006) sees how NCLB leads officials to encourage academic skills to be taught in preschool so students can master the goals of kindergarten. One such initiative can be seen in Good Start, Grow Smart. After Good Start, Grow Smart started standards for preschool; other states have adopted state standards for preschools in order to present a more academic program to align with K-12 standards and accountability. Educators fear this increase of academic standards will damage and have lasting negative consequences on young students which may cripple 


\section{PREPARING PRESCHOOLERS}

them before they have even started elementary school. This drastic difference in programs can be seen in reading and mathematics lessons. As with elementary schools, preschool teachers are preparing lessons for the test rather than encouraging the development of the whole child. Children need individual instruction as each child learns and grows at a different rate, rather than a scripted curriculum. Stipek voices the concern of others who "worry that children are not, for example, learning to cooperate with others; to plan, organize, and complete multidimensional, long-term tasks; to enjoy and participate in the arts; and to develop healthy physical habits and athletic skills" (2006, pg. 459). Stipek concludes by offering several practical strategies/activities to keep young children engaged and learning in practical real-life situations such as dramatic play time offers.

\section{Conclusion}

Preschool has its foundation in the work of Frobel and Montessori, along with the contributions of Dewey, Piaget and Vygotsky. Research has been conducted to ascertain developmentally appropriate practices for preschoolers. At the same time, a rise in behavioral science and national and state standards have taken over elementary schools. As kindergarten joined with elementary school, the elementary school practices have overshadowed and altered Frobel's original kindergarten. The fate of preschool still hangs in the balance as each preschool prepares students for a more academic, behaviorist kindergarten while still asserting developmentally appropriate practices. 


\section{Chapter 3: Methodology}

\section{Introduction to the Method}

Several researchers have used an ethnographic or phenomenological approach to studying schools, in particular preschools. These studies have focused on observing participants in a specific environment and drawing conclusions from the evidence. Occasionally, researchers have specific questions for an interview with participants, but often times they simply ask probing questions as the need arises. These studies look at the participants' perceptions of the classroom and school life in general. Direct communication and follow-up conversations are needed in order to understand perceptions.

Case studies differ from ethnographies and phenomenologies in that they do not have to study the people themselves. A person, group, place, organization, event, activity, or process can be classified as a case study. Johnson and Christensen (2008) explain a case "as a bounded system" in which the researcher tries to comprehend the parts that define that specific system.

\section{Rationale for the Method}

A case study allows for generalizations and insights into how something works or functions. This research aims to find generalizations about how preschools balance DAP and academic preparation. By studying a nationally operated preschool, conclusions from one branch can be applied to all branches and have a fairly high carry-over rate to 


\section{PREPARING PRESCHOOLERS}

other preschools that follow a similar structure and program. These generalizations can be limited based on an individual branch's practice in regards to the documentation provided from the company. This research focuses on the curriculum and practices used, rather than participant perceptions. This approach does not require interviews or personal contact with participants which need permission. Observations will be used to validate documentation and structural design unobtrusively.

This type of case study allows more freedom in some respects, which can yield a greater amount of information to glean. Given the vulnerability of preschoolers, denial of parental consent for interviews and extended observations can hinder the amount of information available in ethnographies or phenomenologies. By not conducting interviews or extended observations, consent is not needed. Likewise, the administrative staff does not feel any threat or inconvenience from a stranger researching their school. Documentation remains natural and unadulterated since it does not need to impress or keep up appearances or standards. Since documentation about schools tends to be readily available for parents, such forms and guidelines required for evaluation can be easily accessed. Copies may be taken from the premise and studied outside the natural environment beyond school hours.

In general, preschools prepare students for their future school life. This can include behaviors, requirements, expectations, or roles. While these may not be spelled out specifically, what a school values and expects from students often is clearly stated in some form of documentation. This study focuses on how the child care center prepares preschoolers for kindergarten through academic preparation and DAP seen in the documentation and validated through an unobtrusive observation. The structural 


\section{PREPARING PRESCHOOLERS}

environment and paraphernalia also indicates what the school values. This can easily be observed through a school tour without disturbing classrooms or staff.

\section{Population of the Study}

KinderCare meets the needs of working families. Their hours of operation, from 6:30 a.m. until 6:30 p.m., encourages working parents to drop off and pick up their children as part of their work commute. They offer flexible hours to accommodate varying work schedules, not necessarily following any particular school schedule. Beyond preschool, they offer before and aftercare programs for school-aged children with transportation to and from the necessary elementary schools. KinderCare closes for the major national holidays and a teacher in-service day, totaling eight days off a year. They offer full day programs for their enrolled school-aged children when schools close beyond national holidays (e.g. teacher in-service or Christmas break).

While inner city and rural families have access to KinderCare, facilities provide more convenience to the suburban areas directly surrounding them. Branches are located within residential areas outside major city limits, but within large population centers. Ethnicity of the student population depends on the composition of the neighborhood areas surrounding the branch. Socio-economic status generally reflects middle class families interested in childcare beyond a babysitter.

KinderCare welcomes children as young as six months into their program. They desire to help educate children from infancy through elementary school. During elementary school hours, only infants through pre-kindergarten aged children attend KinderCare. Before and after school hours, kindergarteners through age twelve attend 


\section{PREPARING PRESCHOOLERS}

KinderCare as well. The summer program accommodates all ages up to twelve years of age.

KinderCare employs childcare providers with associate and bachelor degrees in the education field. They also have aides with 90 credit childcare licenses or a degree. KinderCare also offers tuition reimbursement for employees attaining further education.

The KinderCare facility visited for this research is located along the east coast of the United States. Several large cities, including the state capitol, skirt the facility. The area surrounding the facility is considered primarily a residential area with only gas stations, fast food and grocery stores. Families of low-middle to lower socio-economic status constitute a large portion of the population. The residential area serviced by the facility is predominately Caucasian, African American and Hispanic with few Asians. The students of the facility match the local population.

\section{Procedure}

Initial contact with KinderCare was made via a phone call. This conversation informed the director of the facility about the research aim and her role in the case study. She received a basic list of the documents necessary for review and a request for a brief tour of the facility. At that time, she had the opportunity to ask clarifying questions and/or refuse participation in the study. She agreed to the study and set a time for meeting in person and viewing the facility based on her schedule and convenience.

The documentation gathered consisted of a family handbook and access to the website for that specific KinderCare for further literature on the program. The data was coded based on variables such as child-centered (c-c) or teacher directed (t-d) instruction, DAP or didactic instruction (di). Other data included academic preparation in regards to 


\section{PREPARING PRESCHOOLERS}

curriculum, activities/schedule, classroom supplies/materials, and environment, such as signs, posters, pictures, bulletin boards, welcome center and promotional paraphernalia. Two observational days were scheduled to see the documentation in action and compare the written values with the practiced values. One day was spent with the two's and three's classes and the other day focused on the four's class and preparation for kindergarten. The data gathered during these observations followed the same coding as listed above. Any follow-up questions for clarification were asked and answered by the director via e-mail or phone conversation. Based on these findings, generalizations and conclusions were drawn regarding kindergarten/school preparation of KinderCare and preschools in general.

A tape recorder aided in field notes from the outside environment and structure of the facility. The director and her assistant gave a brief tour of the facility pointing out documentation along the way. No notes or photographs were taken during the tour (photography was prohibited). At the end, the director supplied additional documentation available, along with her personal e-mail and phone number for any follow-up questions or needs. Immediately following the visit, field notes were recorded based on the tour and observations of posted documentation.

During the two observational sessions, field notes were taken and sketches were made of the classrooms layout and design. The classroom schedule and routine for all three classrooms were noted for structured learning activities as well as daily activities (snack, lunch, nap, unstructured play time). Instances of discipline and implementation of rules were documented. Each piece of data was evaluated based on three main categories: documentation, classroom practices and environment. Once divided into 


\section{PREPARING PRESCHOOLERS}

these groups, each piece of data was further categorized as child-centered or teacher directed and/or a DAP. This data was coded using the same method as mentioned above. Each piece of data was compared to the research found on DAP and child-centered classrooms. 


\section{Chapter 4: Results}

\section{Introduction}

The collection of data has been divided into three groups: documentation, classroom practices and environment. Documentation includes information on the KinderCare website, the Family Handbook, and communication between teachers and the parents. Classroom practices focuses on the scheduling of the day and content as well as the curriculum. This data comes mainly from observations and field notes. The environment includes both the outside and inside school areas, including student areas

and adult areas. Information from the environment also looks at the materials provided and the organization/layout of these areas.

\section{Description of the Data}

\section{Documentation}

KinderCare desires to develop "the whole child — of giving each child the skills he or she needs to excel socially, emotionally, physically and, most important, intellectually" (Knowledge Universe, 2010). KinderCare acknowledges and encourages the unique strengths and weaknesses of each child and tailors individualized curriculum to meet those needs (Knowledge Universe, 2010). KinderCare espouses this philosophy in their Family Handbook as their written, formal guidelines they actively work to accomplish. 


\section{PREPARING PRESCHOOLERS}

Each parent receives the Family Handbook when they register their child for the program. This handbook details KinderCare's educational programs, child care and health, safety and security, operational procedures, and family communication and involvement. The handbook emphasizes a program that adapts to the needs and interests of each child. In order to help develop the whole child, KinderCare focuses on play experiences. Each program outlined, reiterates individual attention to children, as well as time for developing social and academic skills, all the while expanding each child's creativity. The prekindergarten and kindergarten programs aspire to develop life-long learners while laying the foundation for each child's future education. Children can participate in special additional programs such as Spanish, cooking, music, active (health and movement), science, math, reading, and phonics. The handbook informs parents of KinderCare policies and procedures in regards to how they operate their facilities.

KinderCare provides much of their documentation about their programs and community involvement on their website. Drop-down tabs across the top provide easy access to center information, programs and curriculum, information about KinderCare, as well as resources for parents. Parents can use the KinderCare website to pay their tuition online, view their calendar with upcoming events and reminders as well as a wealth of resources for caring for their child at home and through a center. Parents also have the option to receive e-mail notifications about their center's programs and the corporation's promotions and activities. The website also provides a link to sign-up interested viewers to receive a monthly newsletter and promotional discounts.

Outside each classroom, a poster informs parents of their weekly or bi-weekly theme along with the activities they have participated in each day. Weekly letters about 


\section{PREPARING PRESCHOOLERS}

their theme and learning objectives are sent home. Each day, children take home a daily progress report concerning the child's development (toileting, meals, etc.). The teacher posts a lists of activities completed each day along with other points of interests for the parents to read when they pick up their children.

\section{Classroom Practices}

KinderCare offers seven age-appropriate classrooms for their students: Infants, Toddlers, Discovery Preschool, Preschool, Prekindergarten, Kindergarten and SchoolAged. Students move up in classes based on their birthday. The infants through preschool classrooms service the students for no more than a year (6 months - one year, one - two years, two - three years, and three - four years). Prekindergarten is intended for students four to five years old; however, those students with a birthday after September can repeat the program until they meet the state's birthday requirement for kindergarten (five by September $1^{\text {st }}$ ). The School-Aged classroom has an area for younger and older students to engage in educational enrichment programs as well as complete their homework, if desired. KinderCare also offers a variety of enrichment programs students can participate in during the afternoons, including, Spanish, phonics and cooking. The infants and toddlers programs reflect each child's own personal needs with activities developed to reach their specific goals.

KinderCare opens at 6:30 a.m. and provides breakfast and quiet learning activities

for students in Discovery Preschool, Preschool and Prekindergarten until 9 a.m. at which time the structured school time begins. The Discovery Preschool and Preschool programs follow a very similar schedule during the day. Based on observations, Circle Time includes singing songs, introducing each other while practicing different emotions, 


\section{PREPARING PRESCHOOLERS}

and reviewing the calendar (date, months of the year, days of the week, colors and dressing the weather bear). During this time, teachers review the alphabet, numbers, and the theme of the week through songs, movement, books and games.

The students were dismissed to use the bathroom and wash their hands for snack following Circle Time. When the students finish their snack, they had free play time at centers in the classroom. Each center relates to the theme they are currently studying. Students helped clean up after center time and then waited on the carpet while students with sunscreen had it applied before going outside. The Discovery Preschoolers use the same playground as the Toddlers, while the Preschoolers and Prekindergarteners share their own playground. After outdoor play, the students came in to get ready for lunch (bathroom break and wash hands). While lunch was being served, the cots were set up in the classroom for the students to have their nap. After about a two hour nap, the students received another snack and prepared to spend the afternoon outside, since the weather permitted.

During the observation, teachers spent the majority of their time getting supplies ready and working around the classroom before Circle Time. Children enjoyed playing and interacting with other children. Teachers in the Preschooler's classroom had a bit of a challenge corralling children to sit quietly with their hands in their lap after free play time. After Circle Time, children were left to their own devices while the teachers helped students use the bathroom and prepare snack. Students moved about the classroom getting into trouble as they continued to explore the classroom and play, rather than sitting at the tables. Several children spoke to me about things in the classroom they were learning or had learned. Unfortunately, teachers saw this as the children not 


\section{PREPARING PRESCHOOLERS}

listening and bothering me, instead of them sharing their knowledge and showing what they have learned.

Prekindergarten starts their Circle Time about 9 a.m. and during the observation they reviewed what they have learned and previewed what they will learn during the week. They discussed the theme, letters, journal activities, craft projects and reading a story. During that time, some students were pulled for a special program to another classroom that day. After about an hour of sitting in chairs around the teacher, the students used the bathroom and washed their hands for snack. As a transition between snack and outdoor play time, the students sat and sang a few songs they had learned. Some students involved in the Spanish program remained in the classroom while the rest of the class went outside. After outdoor play, the students came in to get ready for lunch (bathroom and wash hands). While lunch was being served, the cots were set up in the classroom for the students to have their nap. After about a two hour nap, the students played in the classroom at the different centers. During this time, the elementary students who attend KinderCare after school were picked up and brought to KinderCare. The oldest Prekindergarteners went with the elementary students to a different room where they engaged in learning activities or worked on homework. The other Prekindergarteners went outside to play for the afternoon, since the weather permitted. In the Discovery Preschool classroom, the teachers ask the students questions about the rules; for example, is that where the car goes? The teachers use redirection when student conflict arises. In the Preschool classroom, the teachers primarily called students out for their behavior and used time away from the group to enforce proper behavior. The Prekindergarten classroom used rhymes like "1, 2, 3, eyes on me, 1, 2, 


\section{PREPARING PRESCHOOLERS}

eyes on you" to gain attention. They used a combination of calling students out on their behavior, explaining the reason for wrong behavior and talking to parents about poor behavior. The Prekindergarten class was the only room that had clearly listed and posted rules: We follow rules - "we listen to our teacher, we walk inside and run outside, we keep our hands to ourselves, we are nice to all our friends, and we have fun."

Students in the Prekindergarten, Kindergarten or School-Aged programs can participate in scheduled field trips - usually offered during KinderCare's Spring, Summer or Winter break programs. KinderCare takes full responsibility for students on their field trips; including students whose parents chaperone. They provide transportation and any other necessities during the trip. For those students in the younger programs, KinderCare offers on-sight programs such as magicians, puppeteers or singers.

KinderCare encourages students to continue in their program from infancy through twelve years of age. They also encourage their students to enroll in their summer programs; therefore, KinderCare does not have end of the school year promotions or beginning of the year activities. Once a month a parent orientation is held in which the parents can also view the facility and meet the staff. Enrollment is open and continuous based on current availability.

\section{Environment}

The brick facility has the familiar red-roofed entrance with the bell steeple, like their logo, red doors and red gutter system. A chain linked fence surrounds the property and encloses the two playgrounds, one on either side of the building. At the entrance of the parking lot, a large promotional banner announces enrollment for the spring break session. The entranceway looks well maintained with shrubbery as well as a couple of 


\section{PREPARING PRESCHOOLERS}

large barrel baskets with fresh flowers planted. At the entrance to the building, a writeerase board welcomes and reminds parents of important information. Through the front doors is a little entranceway with a keypad security system used to enter the building and a sliding glass window to the right side. The window looks into the Director's office with the Assistant Director's office located behind that.

Inside the entrance, the welcome area is off to the right side and a straight hallway provides access to all the classrooms and kitchen. The welcome area includes a table which holds the binders designated for parental signing in and out. Other promotional handouts lay on the table as well as flyers posted on the board. This area is also where children can take home a daily snack - a cookie on Friday.

Student artwork decorates the hallway walls, as well as classroom walls and ceilings. The Infant and Toddler rooms are first on the left across from the kitchen and staff area. Beyond the kitchen, on the right, is the Preschool classroom with the SchoolAged classroom beyond that. On the other side is the entrance to the Prekindergarten and Discovery Preschool classrooms. Each classroom has access to the outside playgrounds; however, the Prekindergarten class crosses through the School-Aged room to use the playground for older children.

The Toddlers and Discovery Preschoolers share one playground surrounded with a cement path and area for a sand table and sidewalk chalk. Several tricycles, a couple ride-and-walk cars and scooters are available for the children to ride around the playground. A large and small play set with a slide is enclosed with a bumper and filled with mulch. A bench and trash can are available near the grass area. The Preschoolers, Prekindergarteners and School-Aged students share the other playground. This area has a 


\section{PREPARING PRESCHOOLERS}

large grassy field for the students to run around as well as a similar play area for tricycles and equipment on a mulched surface. A small basketball court with a standard hoop and basketball are also available for the students to play with. One teacher even tosses a football with students occasionally.

All meals are provided by KinderCare on the premise. They follow the menu designed by their registered dietician to provide healthy, well-balanced meals and snacks for their students and staff. This particular KinderCare offers breakfast, morning snack, lunch and afternoon snack. Food is delivered to each classroom with marked utensils for a serving size. Students use paper napkins, plates and cups; however, they have metal forks and spoons depending on what type of food they have. Students may have as much as they want. For naptime, each student has their own cot and sheet provided, but they may bring something from home to sleep with. In addition, the Prekindergarteners may have up to three books to read or look at while they rest.

The Infant and Toddler room has typical furniture, like cribs and high chairs as well as soft mats and colorful wall hangings for children to feel at home. The rooms have plenty of toys for the children to play with and interact with the teachers. Due to the individualized programs for each student and lack of academic curriculum, this room was not further observed.

All the other classrooms (Discovery Preschool, Preschool and Prekindergarten) have two tables with eight or nine chairs each and sixteen or eighteen cubbies along the wall for each child to store their personal belongings. A storage table holds sensory objects, an assortment of age-appropriate manipulatives, animals, cars, legos and blocks for the children to use as desired. Around the room, children have access to an easel for 


\section{PREPARING PRESCHOOLERS}

art, a housekeeping area with a kitchen and dress-up clothes, and a bookshelf full of books with a comfortable sitting area. Each room has a designated area for whole class learning with a calendar, weather chart and bear to dress. Children's artwork hangs down from the ceiling and decorates the walls. The walls also have pictures and posters that support the current theme or content being learned, such as community helpers, families, and emotions. Small centers provide children interaction with letters and numbers. The Discovery Preschool room also has a small slide for recreation while the Prekindergarten room has a couple computers for children to use.

\section{Data Analysis}

\section{Documentation}

The Family Handbook has a balance between developmentally appropriate practices and academic preparation. The academic preparation progresses gradually with each age group; keeping in mind the developmentally appropriate expectations for each age and using DAP. It presents a very child-centered and individualized curriculum with plenty of room for adaptations. KinderCare recognizes each child develops differently, which requires a unique curriculum for each child; rather than simply following a cookiecutter, or one-size-fits-all approach. While KinderCare does mention a standard curriculum, they explain it as providing a baseline with multiple options for teachers to discern which best fits the needs of his or her children. The handbook expresses DAP and developmentally appropriate academic preparation -- keeping in mind DAP with an engaging, child-centered classroom.

The KinderCare website espouses much of the same information found in the handbook throughout their tabulated information. The website goes into more detail 


\section{PREPARING PRESCHOOLERS}

about their educational philosophy: developing the whole child with academics comprising a small part of the program. The focus continues to remain on each individual child and making the learning experience fun, engaging and interactive. KinderCare expresses a desire to be an extension of the family and community, so the resources provided for parents meets them where they are and provides ways to develop DAP at home. As expected, the testimonials and other such information depict an interactive, engaging environment in which children's curiosity and creativity grows while preparing them for the next step and elementary school.

\section{Classroom Practices}

The way KinderCare divides their classrooms and moves children from one group to the next follows DAP. Children stay with other children at about the same developmental stages within a year based on their birthday; rather than the calendar school year. Parents have the flexibility to bring and pick up their children as needed; not based on an academic time frame such as typical preschool programs. Field trips, presentations and programs try to expose the children to new adventures while still providing some academic enrichment to build a foundation for the future. The activities take into account DAP and maintain a child-centered environment.

The academic portion of the day happens primarily during the group Circle Time. This time largely reflects a typical classroom environment in which teachers expect students to sit quietly and absorb the information they provide. From observations, students engaging in the lesson by interacting with the information; rather than passively sitting, "disrupt" and "distract" the learning, thus becoming behavioral problems. While the Discovery Preschool and Preschool classrooms varied the activities presented during 


\section{PREPARING PRESCHOOLERS}

Circle Time, the teachers still expected the children to behave under control like students in elementary school do. In the Prekindergarten classroom, children sat in their chairs for almost an hour while the teacher expected them not to fidget. This time does not reflect a child-centered classroom, an engaging environment, nor does it allow for creative expression. The information provided did not stem from the children's curiosity or take into account any specific needs of the children. Teachers followed the curriculum provided and chose the activities they thought best, not necessarily based on the children in their classroom.

During unstructured learning time, children explored the classroom and learning centers provided. Teachers used this time to take care of classroom paperwork or prepare for the next thing on the agenda. Often the two teachers in the classroom would talk with each other (usually about work), completely oblivious about the children, let alone fostering/guiding their learning. Children had free reign to do as they pleased with little communication from the teachers; unless something caught their attention (e.g. a child being too loud or crying from being poked with a fork).

\section{Environment}

The inside walls and ceilings display children's artwork and children's photographs, rather than store-bought posters and decorations. This celebrates each child's unique abilities and gives value to their work. It also allows for child input, instead of the teacher deciding what the children should look at or how realistic artwork should look like. The artwork also went along with their current theme, so anyone walking in could identify the theme, and children would have a constant 


\section{PREPARING PRESCHOOLERS}

reminder/reference. The use of creative art projects also shows KinderCare's desire to develop the whole child and engage the children in creative projects.

Several classrooms used photographs of the children to express different feelings/emotions and several had a space for each child to bring in photographs of his or her family. This allows the childcare environment to naturally extend from the home environment. All the classrooms have age-appropriate and developmentally appropriate furniture and activities in which the children may engage. The classrooms have a variety of fine motor, gross motor, listening, creative, and cognitive activities for the children. Overall, the classrooms look developmentally appropriate with the correct ratio of materials to promote the whole child while engaging children through interaction.

Both playgrounds provide a safe and age-appropriate place to develop gross motor skills and social interactions. The variety of toys and equipment allow for the development of the whole child, not just one or two motor skills or simply a place to run off energy. The meals provided offer a balanced, healthy diet to help children grow and develop physically as well as fueling their bodies to grow cognitively. The building as a whole provides a safe, healthy environment for the children to learn and grow.

\section{Conclusion}

KinderCare espouses DAP both in their Family Handbook and on their website. They promote the development of the whole child in an engaging, interactive, childcentered environment. Their building offers a safe and healthy environment for the children to learn and grow in all areas. Based on the literature KinderCare provides, the environment reflects their goals and desires. KinderCare supplies all the necessary materials for age-appropriate exploration and creativity to take place. 


\section{PREPARING PRESCHOOLERS}

Unfortunately, the actual classroom practices fall short of the intended outcomes.

Children explore without the necessary teacher follow-through. Teachers expected inappropriate developmental requirements, and at times, squelched appropriate learning experiences. What actually takes place in the classroom, does not match what KinderCare touts as their philosophy; in some cases it contradicts their philosophies. 


\section{Chapter 5: Discussion and Implications}

\section{Introduction}

Current research of preschools has shown a shift away from developmentally appropriate practices towards a more didactic teaching approach. Despite developmentally appropriate materials and environment, KinderCare may be following the same pattern. According to the observations conducted, a teacher-directed classroom with didactic instruction has trumped the child-centered, engaging classroom espoused. The research studied has offered several possibilities for why this phenomenon has occurred.

Overwhelmingly, the legislation NCLB receives the blame for causing a pushdown effect in the curriculum. Increasingly, it is believed that in order for elementary students to come prepared for the rigorous content, they need to have an academic foundation provided in preschool. Researchers agree that preschools have risen to the occasion and dropped the "unnecessary" unstructured play time in favor of more structured teaching time. Parents want their children to be academically prepared for school, and even look for special programs to help their children excel academically.

Another factor examines teacher preparation for preschool, as opposed to elementary school. Researchers point out that not all teachers have received adequate training in DAP or how to identify the needs of each individual child. Without proper training, teachers rely on provided curriculum and themselves, which creates a teacher- 


\section{PREPARING PRESCHOOLERS}

centered, didactic classroom, despite what the curriculum intends. Likewise, elementary school training does not discuss the unique role play has in developing the whole child nor its critical role in a preschool program in order to use DAP while teaching.

The last factor questions preschools desire to associate with elementary schools. In order to distance itself from the typical view as a babysitting service, preschool has turned to kindergarten and elementary school practices to align with academic preparation. This search for credibility sacrifices DAP and the child-centered, engaging classroom of the preschool not found in elementary schools.

\section{Interpretations of the Results}

KinderCare understands the research on the development of young children. They have created and designed a program that includes DAP as well as engages children to use their creativity and foster their natural curiosity. Even the facility visited has received NAEYC's accreditation considering their DAP and understanding of developing the whole child. KinderCare offers special programs to enrich children in music, cooking and foreign language as well as other academic areas like math, science, and phonics. The classrooms group children close in age, moving them to the next classroom according to their birthday, instead on the calendar. This helps keep children close developmentally so teachers can tailor the instruction to meet the individual needs of the children.

While KinderCare works to meet the developmental needs of the whole child, the classroom practice presents the key determining factor in whether or not those goals are carried out. The observations showed that the facility uses the curriculum provided and tries to follow KinderCare's intentions to provide DAP. Unfortunately, as research has 


\section{PREPARING PRESCHOOLERS}

shown, curriculum cannot instruct teachers how to scaffold learning, guide structured play or intuitively present the information each individual child needs. When teachers follow a specific curriculum, they naturally take on a teacher-centered and didactic approach, rather than child-centered and adapting lessons or taking advantage of teachable moments.

Since KinderCare seeks to provide a learning environment for all children six months to twelve years old, they also focus on academic preparation. Despite the desire of KinderCare to develop the whole child, academics takes a prominent place in the schedule. The teachers expect the children to sit quietly and listen attentively while they dispense the knowledge. While NAEYC and DAP encourages academic preparation and school readiness, they do not condone passive learning or teachers dispensing the information with no interaction from the children. KinderCare has age-appropriate themes for weekly learning; however, the teachers teach according to the didactic approach of elementary schools.

While the teachers tried to follow their schedule and routines, the children often had their own ideas and plans. Discipline became a recurring problem throughout the day and especially during lessons. The more structured the time, the more frequent the infractions. Typically, the children wanted to continue to explore their classroom or interact with their friends, instead of listening to the teachers to clean up or transition to quiet learning. In the older classrooms, children wanted to share with me what they had learned or something from the weekly theme. The teachers saw this as bothering me and quickly shooed the children away, cutting off their sharing of new information. Teachers focused on the need to follow the curriculum and documentation while staying on 


\section{PREPARING PRESCHOOLERS}

schedule. They did not have time for teachable moments, flexible learning times or child-centered lessons.

\section{Potential Applications of the Findings}

KinderCare does a good job preparing documentation and curriculum expressing their understanding and desires for the development of the whole child. Despite all their efforts, teachers cannot focus on the child if they focus on covering the curriculum and following a tight schedule. They lose sight of the real purpose; to guide and foster children by using their natural sense of curiosity and creativity. The results of this study should begin a conversation for KinderCare to re-examine the way they train their teachers and prepare their materials.

According to the research, several founders of early childhood programs did not want to leave specific curriculum to follow in order to guard against teachers putting more importance on the curriculum than the child. KinderCare does a good job selecting appropriate themes and activities for children in which to participate. Unfortunately, the teachers use the curriculum more than following the needs of the children. KinderCare needs to find a balance between providing themes and activities while still allowing for flexibility to meet individual needs.

Teachers could also use more training in how to tune into the needs of each child and ways to foster their natural development. Not all education programs emphasize child develop and the unique training necessary for developing the whole child through play. KinderCare cannot rely on outside sources of education to provide the important training to meet their standards of DAP. Teachers must have specific training for cultivating life-long learners with a natural inquisitive mind through real life experiences. 


\section{PREPARING PRESCHOOLERS}

KinderCare well understands DAP and NAEYC's standards and principles; they need to work on transferring that understanding and knowledge to their teachers to build the credibility of their program.

Not only will training in meeting the individual needs of the children help the teachers, they could also use more training in classroom management. Most of the discipline problems occurred during the structured learning time because the teachers had an agenda to follow and they did not want the children to interrupt their plan.

Unfortunately, without feedback from the children, the teachers do not know if they are meeting the needs of the children nor can they gather information to further develop their lessons. While teachers need to maintain control and order in the classroom, valuable information can be gleaned through discussion and discourse with the children. Teachers need proper training to maintain a child-centered classroom designed to foster each child rather than present a mass-produced curriculum.

This information not only helps KinderCare's administration and teachers, but also the parents who trust their children will receive the type of learning environment described in the literature and seen from a tour of the facility. Since parents cannot observe the classrooms before registering their child and most parents enrolling their child in KinderCare work while their child attends the facility, they believe their child receives what the program says it offers. Parents trust KinderCare to develop their whole child through engaging practices - most parents do not fully understand or realize DAP, although they expect KinderCare follows them based on the literature they receive. Parents need to pay closer attention to what actually happens in the classroom instead of getting caught in the snow job from the promotional branch of KinderCare. 


\section{PREPARING PRESCHOOLERS}

\section{Biblical Response and Implications}

Most research surrounding DAP comes from the study of child development and theories of development from Piaget and Vygotsky. Recently, brain-research has collaborated the way the brain develops with these earlier theories. While these researchers and theorists have sought to understand the way humans develop, looking to God may provide a clearer picture.

God created man in His own image with certain communicable attributes. Looking at the creation process, God shows His creative being as He spoke the universe, planet earth and animals into existence. God demonstrates His creativity and hands-on interaction with His world from the beginning. In His image, human beings possess a certain amount of creativity and hands-on interaction. Therefore, children need time and experience to develop their creativity and hands-on experiences. Developmentally appropriate practices take both of those into consideration as key for child development.

When God created the world, He provided the earth with everything man would need, but He did not tell man everything. God allowed man to discover how the world works. He mandated man to fill the earth and subdue it; in other words, God put man in charge of working the earth and taking care of it. God also created the earth with certain safeguards against man harming the earth. If man did something to hurt the earth, he would stop and the earth would heal itself. God wanted man to explore the world and learn through trial and error and through his explorations; not through lecture or direct teaching from God. Again, DAP encourages hands-on exploration and learning from mistakes. Mistakes provide opportunities for teachable moments and understanding a concept more thoroughly. 


\section{PREPARING PRESCHOOLERS}

While understanding the character of God and His creation provides insight into human development, Jesus demonstrates good teaching techniques. Jesus met the people where they were and brought them to the next level; much like scaffolding. Jesus understood the people around Him and He adjusted His message to provide just what His listeners needed to hear. While Jesus has omniscience as the Son of God, He also took the time to build relationships with the people and invest in them. Teachers need to know their students in order to tailor lessons to meet their current needs and plan how to take them to the next level. By listening to their students and building relationships in order to learn the current level of development, teachers create a child-centered classroom and environment. Scaffolding and a child-centered classroom follow the DAP and NAEYC standards/principles.

Not only does research support DAP, but God designed man to actively engage and explore the world around him. Since God intended man to learn this way, it is critical to foster this learning from a young age and expose young children to develop according to their created nature. Preschool programs need to provide children with hands-on activities in which they can explore their world and environment. As the preschoolers investigate, they will create meaning and learn from their mistakes. Preschools can provide a rich environment for children to explore while teachers work one-on-one with children to help them learn from their mistakes. Teachers ascertain the current abilities of their students and work with them to stretch and grow them to higher levels of abilities and independence. Preschool programs and teachers need the proper training and follow through in order to insure the appropriate development of children. 


\section{PREPARING PRESCHOOLERS}

\section{Strengths of the Study}

This study adds to the body of research examining preschools and their preparation of children for elementary school. The common factors involved in the deterioration of DAP in preschools apply to KinderCare according to this case study. Most research investigates a single preschool, rather than a corporate company, such as KinderCare. Due to the uniform nature of KinderCare, the results of studying them can be far reaching. While this study simply scratches the surface, it also lays the groundwork for further research.

\section{Limitations of the Study}

This study only made observations in one KinderCare facility. The documentation from the Family Handbook and information on the website applies to all KinderCare facilities. KinderCare has nearly 1,700 facilities with over 500 NAEYC accredited (www.kueducation.com); therefore, results from this study may not accurately depict the other facilities. While some factors the company controls, such as curriculum and materials provided, the teacher presentation will vary from classroom to classroom despite company training. Each teacher brings their own background knowledge and experience to the classroom, and this study cannot control for that. The results of this study may be generalized to other branches or at least provide a starting point for further research at another branch.

Due to company policies and the director's availability, time spent in the classrooms was limited. More days in each classroom, spread over several months, would provide a clearer picture of how often teachers use didactic teaching versus DAP in the lessons. While the days picked to observe seemed fairly routine, different content 


\section{PREPARING PRESCHOOLERS}

may be presented in different ways. Teachers seemed familiar with their routine and moved like clock-work, more indicative of a typical day; however, more observations would solidify the evidence found.

This study did not take into account the type of training the company provides for their teachers. Throughout the year, the teachers go to a training session for the curriculum the company provides. The director did not share any information as to how that may affect teacher presentation in the classroom. The training may prepare teachers to teach in a more didactic approach, despite the DAP the curriculum desires to instill. In addition, this study did not look at teacher training or preparation outside of the company. The teacher's educational background will affect how he or she teaches and views the material to present. Since KinderCare hires all levels of education, this study could not determine how that education affected the practices observed.

\section{Suggestions for Future Research}

While this study has scratched the surface of KinderCare and their practices, further research will provide more conclusive information concerning teacher practices. As mentioned above, this study only focused on one KinderCare facility, despite according to documentation KinderCare has at least 500 NAEYC accredited facilities. Observing these facilities would provide more substantial information as to how teachers instruct and present their lessons. Likewise, further research concerning the training KinderCare prepares for their employees would help understand where the disconnect occurs between the documentation provided to their families and what actually happens in the classroom. A more in depth study would offer KinderCare a better overview of 


\section{PREPARING PRESCHOOLERS}

their program and could narrow down factors in order to clearly identify how to solve the disconnect. 
PREPARING PRESCHOOLERS

\section{References}

Blank, J. (2010). Early childhood teacher education: Historical themes and contemporary issues. Journal of Early Childhood Teacher Education, 31(4), 391-405.

Boisvert, R. D. (1998). In Smith P. L. (Ed.), John Dewey rethinking our time. Albany, New York: State University of New York Press.

Bredekamp, S., \& Copple, C. (Eds.). (1997). Developmentally appropriate practice in early childhood programs (Revised ed.). Washington, D.C.: National Association for the Education of Young Children.

Bredo, E. (2003). The development of Dewey's psychology. In Zimmerman, B. J., \& Schunk, D. H. (Eds.), Educational psychology: A century of contributions (pp. 81111). Mahwah, New Jersey: Lawrence Erlbaum Associates.

Brownlee, J., \& Berthelsen, D. (2006). Personal epistemology and relational pedagogy in early childhood teacher education programs. Early Years: An International Journal of Research and Development, 26(1), 17-29.

Brumbaugh, E. (2008). DAP in ECE: RESPECT. Kappa Delta Pi Record, 44(4), 170175.

Bryant, D. M., Clifford, R. M., \& Peisner, E. S. (1991). Best practices for beginners: Developmental appropriateness in kindergarten. American Educational Research Journal, 28(4), 783-803. 


\section{PREPARING PRESCHOOLERS}

Copple, C., \& Bredekamp, S. (2008). Professional development: Getting clear about developmentally appropriate practice. YC: Young Children, 63(1), 54-55.

Darragh, J. (2007). Universal design for early childhood education: Ensuring access and equity for all. Early Childhood Education Journal, 35(2), 167-171.

Fernie, D. E. (1988). Becoming a student: Messages from first settings. Theory into Practice, 27(1), 3.

Freeman, E. B., \& Hatch, J. A. (1989). What schools expect young children to know and do: An analysis of kindergarten report cards. The Elementary School Journal, 89(5), 594-605.

Graue, E. (2008). Teaching and learning in a post-DAP world. Early Education \& Development, 19(3), 441-447.

Gutek, G. L. (2003) Maria Montessori: Contributions to educational psychology. In Zimmerman, B. J., \& Schunk, D. H. (Eds.), Educational psychology: A century of contributions (pp. 171-186). Mahwah, New Jersey: Lawrence Erlbaum Associates.

Inan, H. Z., Trundle, K. C., \& Kantor, R. (2010). Understanding natural sciences education in a Reggio Emilia-inspired preschool. Journal of Research in Science Teaching, 47(10), 1186-1208.

Instructional time in elementary schools: A closer look at changes for specific subjects. (2008). Arts Education Policy Review, 109(6), 23-28. 


\section{PREPARING PRESCHOOLERS}

Johnson, B., \& Christensen, L. (2008). Educational research quantitative, qualitative, and mixed approaches (3rd ed.). Los Angeles: Sage Publications, Inc.

Knowledge Universe. (2012). Retrieved, 2011, from http://www.kueducation.com/

KinderCare. (2012). Retrieved, 2011, from http://kindercare.com/

Langford, R. (2010). Theorizing an early childhood educator's authority for the advancement of social goods. Alberta Journal of Educational Research, 56(3), 291303.

Lillard, P. P. (1972). Montessori A modern approach. New York: Schocken Books.

Lim, B. Y. (2004). The magic of the brush and the power of color: Integrating theory into practice of painting in early childhood settings. Early Childhood Education Journal, 32(2), 113-119.

Linder, S. M., Powers-Costello, B., \& Stegelin, D. A. (2011). Mathematics in early childhood: Research-based rationale and practical strategies. Early Childhood Education Journal, 39(1), 29-37.

Manning, J. P. (2005). Rediscovering Froebel: A call to re-examine his life \& gifts. Early Childhood Education Journal, 32(6), 371-376.

McMullen, M., Elicker, J., Goetze, G., Huang, H., Lee, S., Mathers, C., Yang, H. (2006). Using collaborative assessment to examine the relationship between self-reported 


\section{PREPARING PRESCHOOLERS}

beliefs and the documentable practices of preschool teachers. Early Childhood Education Journal, 34(1), 81-91.

Montessori, M. (1967). The absorbent mind (C. A. Claremont Trans.). New York: Holt, Rinehart and Winston.

Moomaw, S., \& Davis, J. A. (2010). STEM comes to preschool. YC: Young Children, $65(5), 12-18$.

National association for the education of young children. (2012). Retrieved, 2011, from http://www.naeyc.org/

National education association. (2012). Retrieved, 2012, from http://www.nea.org/

Nicolopoulou, A. (2010). The alarming disappearance of play from early childhood education. Human Development, 53(1), 1-4.

Parette, H., Hourcade, J., Dinelli, J., \& Boeckmann, N. (2009). Using clicker 5 to enhance emergent literacy in young learners. Early Childhood Education Journal, $36(4), 355-363$.

Powell, D., Higgins, H. J., Aram, R., \& Freed, A. (2009). Impact of no child left behind on curriculum and instruction in rural schools. Rural Educator, 31(1), 19-28.

Powell, M. (2007). The hidden curriculum of recess. Children, Youth \& Environments, 17(4), 86-106. 


\section{PREPARING PRESCHOOLERS}

Quintero, E. P. (2010). Something to say: Children learning through story. Early Education \& Development, 21(3), 372-391.

Ray, K., \& Smith, M. (2010). The kindergarten child: What teachers and administrators need to know to promote academic success in all children. Early Childhood Education Journal, 38(1), 5-18.

Rogers, S., \& Evans, J. (2007). Rethinking role play in the reception class. Educational Research, 49(2), 153-167.

Rushton, S., Juola-Rushton, A., \& Larkin, E. (2010). Neuroscience, play and early childhood education: Connections, implications and assessment. Early Childhood Education Journal, 37(5), 351-361.

Rushton, S., \& Larkin, E. (2001). Shaping the learning environment: Connecting developmentally appropriate practices to brain research. Early Childhood Education Journal, 29(1), 25.

Schwartz, E. (2008). From playing to thinking: How the kindergarten provides a foundation for scientific understanding. European Journal of Psychotherapy \& Counselling, 10(2), 137-145.

Singer, D. G., \& Revenson, T. A. (1997). A Piaget primer how a child thinks (Revised ed.). Madison, Connecticut: International Universities Press, Inc.

Snow, K. (2011). A bridge between early childhood research and practice. YC: Young Children, 66(4), 63-65. 


\section{PREPARING PRESCHOOLERS}

Spodek, B., \& Robison, H. F. (1965). Are kindergartens obsolete? The Elementary School Journal, 65(6), pp. 300-305.

Stipek, D. (2006). No child left behind comes to preschool. Elementary School Journal, $106(5), 455-465$.

Strong-Wilson, T., \& Ellis, J. (2007). Children and place: Reggio Emilia's environment as third teacher. Theory into Practice, 46(1), 40-47.

Suransky, V. P. (1983). The preschooling of childhood. Educational Leadership, 40(6), 27.

Taharally, C., \& La Fontaine, E. (2007). Developmentally appropriate practice and preschool graduation. YC: Young Children, 62(3), 72-75.

Thornton, L., \& Brunton, P. (2010). All about the Reggio approach. Nursery World, $110(4222), 15-20$.

Trudge, J. \& Scrimsher, S. (2003). Lev S. Vygotsky on education: A cultural-historical, interpersonal, and individual approach to development. In Zimmerman, B. J., \& Schunk, D. H. (Eds.), Educational psychology: A century of contributions (pp. 207228). Mahwah, New Jersey: Lawrence Erlbaum Associates.

Tunnicliffe, K., Chatterton, C., \& Arcari, B. (2006). How to prevent children from being left behind. Teaching Elementary Physical Education, 17(5), 16-19. 


\section{PREPARING PRESCHOOLERS}

Tzuo, P. (2007). The tension between teacher control and children's freedom in a childcentered classroom: Resolving the practical dilemma through a closer look at the related theories. Early Childhood Education Journal, 35(1), 33-39.

Vartuli, S., \& Rohs, J. (2008). Selecting curriculum content that stimulates thought. Early Childhood Education Journal, 35(5), 393-396.

Wasik, B. (2008). When fewer is more: Small groups in early childhood classrooms. Early Childhood Education Journal, 35(6), 515-521.

Woodard, C. (1979). Gifts from the father of the kindergarten. The Elementary School Journal, 79(3), pp. 136-141. 